\title{
Is Your Child Ready to Face the World?: Anupam Sibal (ed)
}

\author{
Published by Penguin Books, Gurgaon, 2015; ISBN: 9780143423140; Pages: 162; Price: \\ INR 250-00
}

Meharban Singh ${ }^{1}$

Received: 3 March 2016 / Accepted: 3 March 2016/Published online: 17 March 2016

(C) Dr. K C Chaudhuri Foundation 2016

The goal of nurturing or parenting is not merely to ensure physical vitality and freedom from disease or disability, but to make sure that children evolve to become productive citizens of society with a well-groomed personality endowed with positive social, moral and spiritual attributes. In this endeavor, "Is Your Child Ready to Face the World?" by Anupam Sibal is an innovative publication to convey useful messages pertaining to the art and essence of living in a society which is mired by inequalities, social injustice and negative human traits.

The book deals with 18 human qualities or virtues and a number of do's and don'ts, which should be inculcated or acquired during childhood to enable them to face the world with confidence and equanimity. The book has an attractive jacket, which entices the reader to pick it and browse through. The initial pages are devoted to a large number of "prepublication praises" by eminent cricketers and journalists including a foreword by cine megastar Amitabh Bachchan.
Interesting personal vignettes, historical motivational stories and quotes by eminent thinkers and leaders spice the publication. It is not a conventional parenting book but a book to promote human wellbeing and happiness by ensuring that children acquire the qualities of head and heart by effective child-parent communication and by emulating the personal examples of their parents and teachers. Most of the desirable human attributes have been covered by the author but there are other celestial principles such as acceptance, dignity or selfesteem, power of prayer, enthusiasm, leadership qualities, silence and solitude with a focus on the "present moment" and virtues of moderation or "middle path" in life also need to be groomed and harnessed to achieve happiness and mental peace.

The book is characterized by a smooth flow of thoughts, lucidity of language with a horde of inspirational messages, and is recommended not only for parents, but also for wouldbe parents and non-parents.

Meharban Singh

drmbsk@gmail.com 